\title{
Bibliography of the Works of Alan G. Gross
}

Poroi 10,2 (December, 2014)

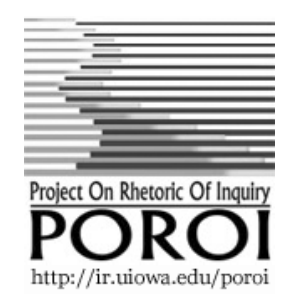

\section{Books}

With Harmon, J.E. Science from Sight to Insight: How Scientists Illustrate Meaning Chicago: University of Chicago Press, 2013.

With Harmon, J.E. The Craft of Scientific Communication. Chicago: University of Chicago Press, 2010.

With Harmon, J.E. (Eds.) The Scientific Literature: A Guided Tour. Chicago: University of Chicago Press, 2007.

- Winner: National Council of Teachers of English best book on science and technology.

Starring the Text: The Place of Rhetoric in Science Studies. Carbondale: Southern Illinois Press, 2006.

Chaïm Perelman. With Dearin, R. Albany: SUNY Press, 2002.

With Harmon, J.E. and M. Reidy. Communicating Science: The Scientific Article From the $17^{\text {th }}$ Century to the Present. New York: Oxford University Press. 2002.

The Rhetoric of Science. 2nd edition. Cambridge, MA: Harvard University Press, 1996.

The Rhetoric of Science. 1st edition. Cambridge, MA: Harvard University Press, 1990.

\section{Collections}

With Walzer, A. (Eds.) Rereading Aristotle's Rhetoric. Carbondale: Southern Illinois, 2000.

With Keith, W. (Eds.) Rhetorical Hermeneutics: Invention and Interpretation in the Age of Science. Albany: SUNY Press, 1996.

\section{Rhetorical Theory and Criticism}

"The Public Sphere and Rhetorical Criticism: A Cautionary Tale." Argument and Advocacy 49 (2012): 141-44. 
"Systematically Distorted Communication: An Impediment to Social and Political Change." Informal Logic 30 (2010): 335360 .

"Rhetoric, Narrative, and the Life-World: The Construction of Collective Identity." Philosophy and Rhetoric 43 (2010): 118138.

"Toward a Theory of Verbal-Visual Interaction: The Example of Lavoisier." Rhetorical Society Quarterly 39 (2009): 147-169.

"Solving the Mystery of Presence: Verbal/Visual Interaction in

Darwin's Structure and Distribution of Coral Reefs." In Ribeiro, H. J., (Ed.) Rhetoric and Argumentation in the Beginning of the XXIst Century. (Pp. 203-22).Coimbra: University of Coimbra Press, 2009. Reprinted in Gage, J.T., (Ed.) The Promise of Reason: Studies in the New Rhetoric. (Pp. 83-102). Carbondale: Southern Illinois Press, 2011.

"Presence as a Consequence of Verbal-Visual Interaction: A Theoretical Approach," Rhetoric Review 28 (2009): 265-284.

"Teksten er Stjerne: Retorikkens Plads I Studiet Af Videnskaberne." Rhetorica Scandinavica 41 (2007): 26-35.

"Habermas, Systematically Distorted Communication, and the Public Sphere.” Rhetoric Society Quarterly 36 (2006): 309330 .

"Scientific and Technical Controversy: Three Frameworks for Analysis." Argument and Advocacy 42 (2006): 43-47.

"Presence as Argument in the Public Sphere." Rhetoric Society Quarterly 35 (2005): 5-21.

"The Role of Subjectivity in Public Controversy." In Barrotta, P., and M. Dascal, (Eds). Controversies and Subjectivity. Pp. 337-352). Amsterdam: John Benjamins, 2005.

“Perelman, Presença ea esfera pública.” In Oliviera, E. C., (Ed.) Chaïm Perleman: Direito, Retórica E Teoria Da Argumentaçào. (Pp. 13-31). Feira de Santana-Baha-Brasil: Universidade Estadual de Feira de Santana, 2004.

"Why Hermagoras Matters: The Fourth Stasis and Interdisciplinarity." Rhetoric Review 23 (2004): 141-55.

"Lincoln's Use of Constitutive Metaphors." Rhetoric and Public Affairs 7 (2004): 173-190. 
"Accounting for Rhetorical Change: The Case of the Founding of the Austrian Academy of Science." Rhetoric Review 22 (2003): 40-60.

"When Nations Remember: Hiroshima in the American Consciousness and Conscience." Prospects: An Annual of American Cultural Studies 27 (2002): 467-488.

With Dascal, M. "The Conceptual Unity of Aristotle's Rhetoric.” Philosophy and Rhetoric 34 (2001): 275-291.

"Rhetoric as a Technique and as a Mode of Truth: Reflection on Chaïm Perelman." Philosophy and Rhetoric 33 (2000): 319335 .

With Walzer, A. and M. Secor. "The Uses and Limits of Rhetorical Theory: Campbell, Whately, and Perelman and OlbrechtsTyteca on the Earl of Spencer's 'Address to Diana'." Rhetoric Society Quarterly 21 (1999): 41-62.

With Dascal, M. "The Marriage of Pragmatics and Rhetoric," Philosophy and Rhetoric 32 (1999): 107-130. Reprinted in M. Dascal (Ed.) Interpretation and Understanding. (Pp. 600622). Amsterdam: John Benjamins 2003.

"A Theory of the Rhetorical Audience: Reflections on Chaïm Perelman." Quarterly Journal of Speech 85 (1999): 203-211.

"What if We're Not Producing Knowledge?" Southern Journal of Speech Communication 58 (1993): 301-305.

"The Experiment as Text: The Limits of Literary Analysis." Rhetoric Review 11 (1993): 290-300.

"The Rhetoric of Science and the Science of Rhetoric." In Halsall, A. W., (Ed.) Proceedings of the Canadian Society for the Study of Rhetoric, Vol 4. 1991-92. (Pp. 8-35). 1993.

"Rhetoric of Science Without Constraints." Rhetorica 9 (1992): 283-299.

\section{Science and Technology}

With Chelsey, P. "Hedging, Stance, and Voice in Medical Research Articles." In K. Hyland and C. Sancho Gunia, (Eds). Stance and Voice in Academic Writing. (Pp. 85-100). New York: Palgrave Macmillan, 2012.

"A Model for the Division of Semiotic Labor in Scientific Argument: The Interaction of Words and Images." Science in Context 24 (2011): 517-44. 
With Harmon, J. "The Structure of PowerPoint Presentations: The Art of Grasping Things Whole." IEEE Transactions on Professional Communication 52 (2009): 121-137.

"The Continuity of Scientific Discovery and Its Communication: The Example of Michael Faraday." Journal of Biomedical Discovery and Collaboration 4 (2008): 1-18.

"The Brains in Brain: The Co-evolution of Localization and its Images." Journal of the History of the Neurosciences 17 (2008): 380-92.

"Rhetoric of Science." In W. Donsbach, (Ed). The International Encyclopedia of Communication. Vol. IX. (Pp. 4339-43). Malden, MA: Blackwell Publishing, 2008.

"Medical Tables, Graphics, and Photographs: How They Work." Journal of Technical Writing and Communication 37 (2007): 419-33.

"Darwin's Diagrams: Scientific Visions and Scientific Visuals." In Fleckenstein, K.S., S. Hum, and L. Calendrillo, (Eds). Ways of Seeing, Ways of Speaking: The Integration of Rhetoric and Vision in Constructing the Real. (Pp. 52-80). West Lafayette, IN: Parlor Press, 2007.

"The Verbal and the Visual in Science: A Heideggerian Perspective." Science in Context 19 (2006): 443-474.

With Harmon, J. "What's Right About Scientific Writing." The Scientist 13 (1999): 20.

“Learned Ignorance.” Two Be: A Journal of Ideas 13 (1998): 94-96.

With Walzer, A. "The Challenger Disaster and the Revival of Rhetoric in Organizational Life." Argumentation 11 (1997): 75-93.

With Harmon, J. "The Scientific Style Manual: A Reliable Guide to Practice?” Technical Communication 43 (1996): 61-72.

"Renewing Aristotelian Theory: Cold Fusion as a Test Case." Quarterly Journal of Speech 81 (1995): 48-62.

With Walzer, A. "Positivists, Postmodernists, and Aristotelians and the Challenger Disaster." College English 56 (1994): 420-33.

"Ending it All: Closure in Science and Its Philosophy." Argumentation 8 (1994): 9-20.

"Does the Rhetoric of Science Matter? The Case of the Floppy Eared Rabbits.” College English 53 (1991): 933-943. 
"Extending the Expressive Power of Language: Tables, Graphs, and Diagrams." Journal of Technical Writing and Communication 20 (1989-90): 221-235.

"A Primer on Tables and Figures." Journal of Technical Writing and Communication 13 (1983): 33-55.

\section{Medical Science}

Gross, A.G. et al. "All That Glitters is Not Gold: A Survey on Acknowledgement of Limitations in Biomedical Studies." PLOS One 8(11) (2013): e73623

With Stärke-Meyering , D. "Medical Advice Editorials: Transferring Medical Science into Clinical Practice." Journal of Laboratory and Clinical Medicine 134 (1999): 185-89.

"Defining Occupational Disease: An Archaeology of Medical Knowledge.” In Huspek, M. and G. Radford, (Eds.) Transgressing Scientific Discourses: Communication and the Voice of the Other. (Pp. 269-287). SUNY Press, 1997.

With Hammerschmidt, D. "The Problem of Biomedical Fraud: A Model for Retrospective and Prospective Action." Journal of Scholarly Publishing 27 (1995): 3-11.

With Hammerschmidt, D. "Withdrawal of Aegis? So What's That?!" Journal of Laboratory and Clinical Medicine 123 (1994): 792-794.

With Hammerschmidt, D. "Allegations of Impropriety in Manuscripts of Aws S. Salim: Examination and Withdrawal of Aegis." Journal of Laboratory and Clinical Medicine 123 (1994): 795-799.

\section{Philosophy of Science}

"Some limits of Non-Dualism." Constructivist Foundations 8 (2013) N. p.

“Kuhn's Incommensurability.” In R. A. Harris, (Ed.) Rhetoric and Incommensurability. (Pp. 179-197). Albany: SUNY, 2003.

"Is a Science of Language Possible? The Derrida-Searle Debate." Social Epistemology 8 (1994): 345-359.

"On Not Taking Sides [in the Derrida-Searle Debate]." Social Epistemology 8 (1994): 373-381.

"Reinventing Certainty: The Significance of Ian Hacking's Realism." In Fine, A., M. Forbes, and L. Wessels (Eds.) PSA 1990. Proceedings of the 1990_Biennial Meeting of the Philosophy 
of Science Association. (Pp. 421-31). East Lansing:

Philosophy of Science Association, 1990.

"Adaptation in Evolutionary Epistemology: Clarifying Hull's

Model." Biology and Philosophy 3 (1988): 185-86.

- See also Hull's comments on Pp. 252-53.

"Philosophy Versus Science: The Species Debate and the Practice of

Taxonomy." In Fine, A. and M. Forbes (Eds.) PSA 1988.

Proceedings of the 1988 Biennial Meeting of the Philosophy

of Science Association. (Pp. 223-230). East Lansing:

Philosophy of Science Association, 1988.

\section{Sociology of Science}

"The Science Wars and the Ethics of Book Reviewing." Philosophy of the Social Sciences 30 (2000): 445-50.

With Harmon, J. and M. Reidy. "Argument and $17^{\text {th }}$ Century Science: A Rhetorical Analysis with Sociological Implications." Social Studies of Science 30 (2000): 371-96.

"Do Priority Conflicts Tell Us Anything About Science?" Science in Context 11 (1998): 161-179.

"The Roles of Rhetoric in the Public Understanding of Science." Public Understanding of Science 3 (1994): 3-23.

"Is a Rhetoric of Science Policy Possible?" Social Epistemology 8 (1994): 273-280.

“The Battle Over Sociobiology.” Social Epistemology 6 (1992): 16574 .

\section{Essay Reviews and Encyclopedia Articles}

"Rhetoric of Science." International Encyclopedia of Communication. Vol. 9. 4339-4342. Oxford: WileyBlackwell, 2008.

With Schiappa E., R. E. McKerrow, and R. L. Scott. "Rhetorical Studies as Reduction or Redescription? A Response to Cherwitz and Hikins." Quarterly Journal of Speech 88 (2002): 112-120.

"Current Trends in Rhetorical Studies in the West." Journal of Jinan University 22 (2000): 34-37. Reprinted in Linguistics and Philology of the People's University of China Social Sciences Information Center 3: 2001. 
"Richard Harvey Brown as Text." Quarterly Journal of Speech 85 (1999): 212-222.

"Science as Culture." American Literary History 7 (1995): 169-186.

"A Disorder of Being: Heroes, Martyrs, and the Holocaust. Postmodern Culture 5.2 (1995):

http://jefferson.village.virginia.edu/pmc/textonly/issue.195/review-2.195

“Theory, Method, Practice." College English 56: (1994): 828-840.

“Rhetorical Imperialism in Science." College English 55: (1993): 82-87.

"An English Professor Looks at the Scientific Article. An Essayreview of Charles Bazerman, Shaping Written Knowledge: The Genre and Activity of the Experimental Article in Science." Studies in History and Philosophy of Science 21 (1990): 341-349.

“The Rhetoric of Science.” In Enos, T., (Ed.) Encyclopedia of Rhetoric and Composition: Communication from Ancient Times to the Information Age. (Pp. 622-627). New York: Garland Publishing, 1996.

"Paradigm Shift." In Enos, T., (Ed.). Encyclopedia of Rhetoric and Composition: Communication from Ancient Times to the Information Age. (Pp. 491-492). New York: Garland Publishing, 1996.

\section{Miscellany}

"The Justification of Prince Hal." Texas Studies in Literature and Language: A Journal of the Humanities 10 (1968): 27-35.

"The Text of Hal's First Soliloquy." English Miscellany: A Symposium of History, Literature and the Arts 18 (1967): 4954 . 